\title{
ANALSIS KORELASI MOTIVASI DAN KEMAMPUAN PEGAWAI TERHADAP KINERJA PEGAWAI DI DINAS PERHUBUNGAN DI SALAH SATU KABUPATEN YANG ADA DI JAWA BARAT: $E X$ POST FACTO STUDY
}

\author{
Nunung Nurhayati \\ Fakultas Ekonomi, Universitas Wiralodra, Jln. Ir. H. Juanda Km 3 Indramayu, \\ hajinunung86@gmail.com
}

Diterima 3 Maret 2020, disetujui 20 April 2020, diterbitkan 30 April 2020

Pengutipan: Nurhayati, N. (2020). Analsis Korelasi Motivasi dan Kemampuan Pegawai Terhadap Kinerja Pegawai di Dinas Perhubungan di Salah Satu Kabupaten Yang Ada Di Jawa Barat: Ex Post Facto Study. Gema Wiralodra, Vol 11, No 1, Hal 90-98, April 2020

\begin{abstract}
ABSTRAK
Penelitian ini bertujuan untuk mengetahui seberapa besar dampak motivasi dan kemampuan pegawai terhadap kinerja pegawai di Dinas Perhubungan. Desain penelitian ini menggunakan ex post facto study, sedangkan jenis penelitian menggunakan causal korealition. Partisipan yang terlibat dalam penelitian ini berjumlah 52 responden. Motivasi pegawai dan kemampuan diperoleh dari hasil kuisioner. Sedangkan kinerja pegawai diperoleh dari data yang diberikan oleh dinas perhubungan terkait dengan evaluasi kinerja pegawai. Analisis data menggunakan analisis regresi berganda. Hasil pengujian menunjukan bahwa kedua variabel independen yang diteliti yaitu variabel motivasi dan kemampuan, terbukti memiliki pengaruh positif dan signifikan terhadap variabel dependennya. Hasil pengujian secara parsial menunjukkan (1) terdapat pengaruh motivasi pegawai terhadap kinerja pegawai; (2) terdapat pengaruh kemampuan pegawai terhadap kinerja pegawai. Selain itu berdasarkan hasil koefisien determinasi menunjukkan (1) dampak motivasi terhadap kinerja pegawai yakni 96,43\% sisanya dipengaruhi variabel yang lain; (2) dampak kemampuan pegawai terhadap kinerja pegawai 96, 43\% sisanya dipengaruhi oleh variabel yang lain; (3) dampak motivasi dan kemampuan pegawai secara bersama-sama terhadap kinerja pegawai sebesar 95,63\% sisanya dipengaruhi variabel yang lain. Implikasi penelitian mengharuskan bahwa pegawai memiliki motivasi dan kemampuan untuk mengerjakan tugas-tugas kedinasan agar bekerja maksimal melayani rakyat.
\end{abstract}

Kata Kunci: Motivasi, Kemampuan, Kinerja, Pegawai, Ex post facto

\begin{abstract}
This study aims to determine how much the impact of motivation and ability of employees on employee performance in the Department of Transportation. The design of this study uses ex post facto study, while the type of research uses causal correlation. Participants involved in this study were 52 respondents. Employee motivation and ability are obtained from questionnaire results. While employee performance is obtained from data provided by the transportation department related to employee performance evaluation. Data analysis uses multiple regression analysis. The test results show that the two independent variables studied were motivation and ability variables, which proved to have a positive and significant effect on the dependent variable. Partial test results show (1) there is an influence of employee motivation on employee performance; (2) there is an effect of employee ability on employee performance. In addition, based on the results of the coefficient of determination shows (1) the impact of motivation on employee performance ie the remaining $96.43 \%$ is influenced by other variables; (2) the impact of employee capacity on employee performance 96 , the remaining $43 \%$ is influenced by
\end{abstract}


other variables; (3) the impact of motivation and ability of employees together on employee performance by $95.63 \%$ the rest influenced by other variables. The implication of the research requires that employees have the motivation and ability to do official tasks so that they work optimally to serve the people.

Keywords: Motivation, Ability, Performance, Employees, Ex post facto

\section{PENDAHULUAN}

Peningkatan kinerja pegawai menjadi tantangan manajemen sumber daya manusia. Sumber Daya Manusia merupakan hal yang sangat penting dalam suatu organisasi, karena keefektifan dan keberhasilan suatu organisasi sangat tergantung pada kualitas dan kinerja sumber daya manusia yang ada pada organisasi tersebut (Dewi \& hardi, 2015). Keberhasilan perusahaan sangat dipengaruhi oleh kinerja karyawannya (Dewi \& hardi, 2015). Hal ini karena keberhasilan dalam mencapai tujuan dan keberlangsungan hidup dinas bergantung pada kualitas sumber daya manusia. Hasibuan (2014:94) kinerja diartikan sebagai suatu hasil kerja yang di capai seseorang dalam melaksanakan tugas-tugas yang dibebankan kepadanya yang didasarkan atas kecakapan, pengalaman dan kesungguhan serta waktu. Pada dasarnya dinas tidak hanya membutuhkan pegawai yang mampu dan terampil tetapi pegawai yang bisa bekerja lebih giat dan berkeinginan untuk mencapai hasil yang optimal dan sesuai dengan tujuan.

Kinerja akan memberikan keuntungan sendiri bagi pegawai, seperti perluasan kesempatan untuk adanya naik jabatan, meningkatkan ketrampilan dan menambah pengalaman yang dimiliki oleh seorang pegawai. Peningkatan kinerja pegawai akan memberikan dampak positif untuk kemajuan dinas. Salah satu faktor yang mempengaruhi kinerja pegawai dalam buku Mangkunegara (2017:13) adalah kemampuan kerja. Kemampuan kerja berhubungan dengan pengetahuan, bakat, minat dan pengalaman agar dapat menyelesaikan tugas-tugas yang sesuai dengan pekerjaan yang didudukinya. Pihak manajemen dinas harus bisa mengembangkan kemampuan setiap pegawainya agar sesuai dengan kebutuhan dinas, karena kemampuan menunjukkan potensi seorang pegawai dalam melakukan pekerjaannya.

Kemampuan kerja pegawai merupakan keahlian yang dimiliki pegawai dalam mengerjakan pekerjaannya. Apabila pegawai mendapatkan kesempatan untuk mengembangkan bakat yang dimiliki, serta menggunakannya secara tepat akan 
berpengaruh pada perkembangan dinas. Selain itu dengan kemampuan yang memadai akan dapat membantu pegawai dalam melaksanakan pekerjaan sekarang dan pekerjaan yang akan datang. Faktor lainnya yang juga mempengaruhi kinerja menurut Mangkunegara (2017:13) pemberian motivasi menjadi kebutuhan penting bagi pegawai. Motivasi ini melalui serangkaian usaha tertentu yang sesuai dengan kebijakan dinas. Dalam memberikan motivasi harus mengetahui karakteristik yang terdapat pada pegawai. Cara yang dilakukan untuk memberikan motivasi antar pegawai tidak sama. Karena pegawai memiliki cara pandang yang berbeda dalam menerima adanya motivasi. Kegiatan tersebut harus diarahkan pada pencapaian tujuan dinas sehingga kinerja pegawai bisa terarah dengan baik. Motivasi dari dinas harus disesuaikan dengan kemampuan yang dimiliki oleh pegawai. Saat pegawai memiliki kemampuan yang rendah, maka dinas harus memberikan motivasi yang khusus dibandingkan dengan pegawai lainya. Sehingga kemampuan dan motivasi memiliki keterkaitan dalam kegiatan dinas.

Kantor Dinas Perhubungan merupakan salah satu dinas yang dibentuk berdasarkan peratauran daerah untuk pembentukan dan susunan perangkat daerah Kabupaten Indramayu. Fungsi Dinas Perhubungan merupakan unsur pelaksana pemerintah daerah di bidang perhubungan, secara umum Dinas Perhubungan mempunyai tugas pokok melaksanakan urusan pemerintahan yang menjadi kewenangan daerah dan tugas pembantuan yang diberikan kepada daerah dibidang Perhubungan. Maka segala bentuk masalah atau hambatan kerja yang ada harus ditangani lebih tepat agar kredibilitas Dinas Perhubungan tetap terjaga. Namun demikian kinerja pegawai masih belum optimal. Hal ini dapat dilihat seperti ketidaktepatan waktu masuk dan cepat pulang. Melihat bahwa pegawai mempunyai tanggung jawab sendiri dan telah menyumbangkan semua tenaganya dengan semaksimal mungkin guna mencapainya tujuan dinas. Sehingga pemberian bentuk motivasi kerja yang diberikan oleh seorang pimpinan terhadap pegawai sangat perlu untuk meningkatkan kinerja guna mencapai kinerja yang lebih baik lagi.

Berdasarkan latar belakang yang telah dijelaskan maka peneliti ingin mengetahui tentang hasil Kinerja pegawai yang dilihat dari segi Kemampuan Kerja dan Motivasi Kerja. Sehingga peneliti mengangkat judul "Pengaruh 
Kemampuan Kerja dan Motivasi Kerja terhadap Kinerja Pegawai” studi kasus pada Dinas Perhubungan Kabupaten Indramayu.

\section{METODE PENELITIAN}

Desain yang digunakan dalam penelitian ini yakni desain ex post facto. Desain ini dipilih karena peneliti menggunakan data kinerja pegawai dari hasil evaluasi pegawai di dinas perhubungan di salah satu kabupaten di Jawa Barat. Sedangkan jenis ex post facto yang digunakan yakni causal correlation. Populasi dalam penelitian ini adalah semua pegawai Dinas Perhubungan di salah satu Kabupaten di Jawa Barat berjumlah 110 orang Pegawai. Sedangkan sampel yang diambil dengan menggunakan rumus slovin yakni berjumlah 55 responden. Study Lapangan (Field Research) Peneliti melakukan penelitian langsung di lapangan untuk memperoleh data yang diperlukan, dalam penelitian ini peneliti menggunakan: (a) Interview (Wawancara); (b) Observasi (Pengamatan); (c) Kuesioner (Angket). Teknik analisis data yang digunakan yakni teknik Analisis Deskritif dan inferensial. Analisis infersensial yang digunakan menggunakan Korelasi Koefisien Sederhana (persial dan Analisis Korelasi Koefisien Ganda (simultan).

\section{HASIL DAN PEMBAHASAN}

\section{Hasil Penelitian}

Untuk menguji kenormalan distribusi sampel yang dilakukan pada penelitian ini agar dapat dipertanggung jawabkan dan digunakan analisis yang tepat maka dilakukan uji normalitas terhadap data sampel yang diperoleh dari motivasi pegawai dan kemampuan pegawai, diuji dengan menggunakan metode Chi Kuadrat.

\begin{tabular}{llll}
\hline Variabel & Chi Kuadrat & Chi Kuadrat tabel & Kesimpulan \\
\hline Motivasi & 3,253 & 11,070 & $\begin{array}{l}\text { Berdistribusi } \\
\text { Normal }\end{array}$ \\
\hline Kemampuan Pegawai & 2,097 & 11,070 & $\begin{array}{l}\text { Berdistribusi } \\
\text { Normal }\end{array}$ \\
\hline
\end{tabular}




\section{Analisis Asosiatif}

Berdasarkan hasil perhitungan terhadap diperoleh korelasi motivasi terhadap kinerja pegawai dapat disimpulkan bahwa nilai $\mathrm{r}_{\text {hitung }}$ sebesar 0,982 termasuk kategori sangat kuat. Selain itu untuk uji korelasi antara kemampuan pegawai dengan kinerja pegawai dapat disimpulkan bahwa nilai $r_{\text {hitung }}$ sebesar 0,978 termasuk kategori sangat kuat. Selain itu, untuk analisis korelasi terhadap motivasi dan kemampuan pegawai dapat disimpulkan bahwa nilai $\mathrm{r}_{\text {hitung }}$ sebesar 0,975 termasuk kategori sangat kuat. Sedangkan untuk analisis koefisien korelasi berganda dari hasil perhitungan diperoleh koefisien korelasi sebesar 0,98 yang termasuk kategori sangat kuat. Oleh sebab itu apat disimpulkan bahwa terdapat pengaruh motivasi dan kemampuan terhadap kinerja pegawai adalah searah dan positif.

\section{Analisis Koefisien Determinasi}

Koefisien determinasi digunakan untuk melihat seberapa besar konstribusi variabel $\mathrm{X}_{1}$ (Motivasi) dan $\mathrm{X}_{2}$ (Kemampuan) terhadap $\mathrm{Y}$ (Kinerja Pegawai), biasanya dinyatakan dengan persen $(\%)$. Koefisien determinasi dapat dihitung dengan rumus sebagai berikut:

$$
\mathrm{Kd}=r^{2} \mathrm{x} 100 \%
$$

Dimana:

$$
\begin{aligned}
& K d=\text { Koefisien determinasi } \\
& r=\text { Koefisien Korelasi }
\end{aligned}
$$

Berdasarkan perhitungan dapat disimpulkan motivasi pegawai memberikan pengaruh terhadap kinerja pegawai di dinas perhubungan sebesar $0,9643 \%$, sedangkan sisanya yang $0,0357 \%$, dipengaruhi oleh faktor-faktor lain yang tidak diteliti. Selain Berdasarkan perhitungan dapat disimpulkan kemampuan memberikan pengaruh terhadap Kinerja Pegawai di Dinas Perhubungan Kabupaten Indramayu sebesar 0,9565\%, sedangkan sisanya yang 0,0435\%, dipengaruhi oleh faktor-faktor lain yang tidak diteliti. Sedangkan berdasarkan perhitungan dapat disimpulkan Motivasi dan Kemampuan pegawai secara bersama-sama memberikan pengaruh terhadap kinerja pegawai di Dinas Perhubungan sebesar $0,9722 \%$, sedangkan sisanya yang $0,0278 \%$, dipengaruhi oleh faktor-faktor lain yang tidak diteliti. 


\section{Pembahasan}

Berdasarkan hasil penelitian diperoleh bahwa terdapat korelasi antara motivasi pegawai dengan kinerja pegawai di Dinas Perhubungan di salah satu kabupaten yang ada di Jawa Barat. Hal ini selaras dengan hasil penelitiannya Anggraeni (2011) motivasi dan kemampuan merupakan faktor-faktor yang bisa meningkatkan dan atau menurunkan kinerja pegawai. Lebih lajut Anggraeni (2011) mengatakan bahwa Motivasi kerja pegawai dinilai sangat baik namun demikian masih terdapat aspek-aspek motivasi yang masih perlu ditingkatkan khususnya dalam aspek tingkat kecemasan dan tingkat rasa kecewa, yang merasa cemas apabila gagal bekerja untuk mencapai tujuan dan mengurangi hambatanhambatan yang datang dari dalam instansi. Selain itu Abdulrachman \& Sustin (2014), hasil penelitian menunjikkan bahwa motivasi dan kemampuan kerja sangat menentukan terhadap peningkatan kinerja pegawai dengan kata lain semakin tinggi motivasi dan kemampuan kerja pegawai maka akan semakin tinggi pula kinerja pegawai. Hal yang sama juga diperoleh dari hasil penelitian Prabadwipa Meidianwar, A. Margono, Djumadi (2014) menyimpulkan bahwa ada pengaruh yang signifikan antara variabel motivasi kerja terhadap variabel kinerja.

Selain motivasi, faktor yang lain yakni kemampuan pegawai. Berdasarkan hasil penelitian diperoleh ada korelasi antara kemampuan pegawai dengan kinerja pegawai. Hal ini selaras dengan hasil penelitian Yuningsih \& Ardianti (2019) terdapat pengaruh kompetensi pegawai dengan kinerja pegawai. Jika didalami kompetensi pegawai pada PT XXX sudah baik, dengan indikator terendah adalah memahami pekerjaan PT XXX sebaiknya terus memberikan pemahaman mengenai pekerjaan kepada para pegawai melalui sosialisasi prosedur dan distribusi dokumen terkait prosedur kepada para pegawai. PT XXX. Selain itu berdasarkan hasil penelitiannya Kartika \& Sugiarto (2014) menyimpulkan bahwa (1) Terdapat hubungan antara pengalaman kerja dengan kompetensi, namun kadar hubungan kedua variabel menunjukkan hubungan yang lemah dan terdapat kecenderungan semakin tinggi pengalaman kerja akan semakin tinggi pula tingkat kompetensi para pegawai. (2) Terdapat perbedaan signifikan atas kompetensi antara pegawai yang memiliki bidang studi administrasi 
perkantoran/kesekretarisan dengan pegawai yang tidak memiliki bidang studi administrasi perkantoran/kesekretarisan. Pegawai yang memiliki latar belakang administrasi/kesekretarisan memiliki kompetensi yang lebih baik daripada pegawai yang tidak memiliki latar belakang administrasi/kesekretarisan. (3). Terdapat perbedaan signifikan atas kompetensi antara pegawai yang mengikuti pelatihan dengan pegawai yang tidak mengikuti pelatihan. Pegawai yang mengikuti program pelatihan memiliki kompetensi yang lebih baik daripada pegawai yang tidak pernah mengikuti program pelatihan. (4). Terdapat pengaruh secara signifikan antara kompetensi terhadap kinerja. Hal ini sejalan juga dengan hasil penelitinnya Sulistiani (2016) yang menyimpulkan bahwa (1) kemampuan kerja di PT. Bahana Cahaya Sejati Ciamis yang memperoleh skor sebesar 2617. Artinya, kemampuan kerja di PT. Bahana Cahaya Sejati Ciamis adalah sangat baik. Selanjutnya (2) kinerja pegawai di PT. Bahana Cahaya Sejati Ciamis yang memperoleh skor sebesar 3242. Artinya, kinerja pegawai di PT. Bahana Cahaya Sejati Ciamis adalah sangat baik. Sehingga kemampuan kerja memiliki tingkat hubungan sedangan dengan kinerja pegawai yaitu sebesar 0,526, sedangkan presentase pengaruh sebesar $27,667 \%$, sementara $72,332 \%$ lainnya dipengaruhi oleh faktor lain yang tidak diteliti.

Hal yang lain, untuk korelasi antara motivasi, kemampuan pegawai secara bersama-sama berhubungan dengan kinerja pegawai. Hal ini berbeda dengan hasil penelitinnya Dhermawan, I Sudibya \& Utama (2012) menyimpulkan bahwa Pada penelitian ini dapat di tarik beberapa simpulan yaitu Motivasi dan Lingkungan Kerja berpengaruh tidak signifikan terhadap kepuasan kerja pegawai. Meskipun para pegawai yang bekerja di Dinas PU Provinsi Bali memiliki motivasi kerja yang baik. Hal tersebut tidak berpengaruh signifikan atau memberikan pengaruh yang kecil terhadap kepuasan kerja yang dirasakan oleh para pegawai tersebut. Hal demikian juga dengan lingkungan kerja karena berpengaruh tidak signifikan terhadap kepuasan kerja maka meskipun lingkungan kerja di Dinas PU Provinsi Bali mengalami perbaikan, hal tersebut tidak berpengaruh terhadap kepuasan kerja pegawainya. Kompetensi dan kompensasi berpengaruh signifikan terhadap kepuasan kerja pegawai dimana semakin baik kompetensi yang dimiliki oleh seorang pegawai, maka akan semakin baik pula 
kepuasan kerja yang dirasakan oleh pegawai tersebut sementara semakin baik Kompensasi yang diterima oleh seorang pegawai, maka akan semakin baik pula kepuasan kerjanya. Namun, hasil penelitian ini selaras dengan hasil penelitinnya Syaifuddin (2016) Hasil penelitian menunjukkan bahwa kompetensi dan motivasi kerja secara simultan mempunyai pengaruh yang signifikan terhadap kinerja karyawan.

\section{KESIMPULAN}

Berdasarkan hasil penelitian dapat disimpulkan bahwa (1) hasil analisis korelasi motivasi terhadap Kinerja Pegawai adalah korelasi 0,982 membuktikan bahwa Korelasi antara Motivasi dengan Kinerja Pegawai dengan kategori Sangat Kuat. (2) Hasil analisis korelasi kemampuan pegawai dengan kinerja pegawai adalah korelasi 0,978 hal itu membuktikan bahwa terdapat korelasi kemampuan pegawai dengan kategori sangat kuat. (3) Selain itu, berdasarkan hasil analisis korelasi motivasi dan kemampuan pegawai secara bersama-sama membuktikan bahwa terdapat pengaruh motivasi dan kemampuan terhadap kinerja dengan kategori sangat kuat.

\section{DAFTAR PUSTAKA}

Anggraeni, N. (2011). Pengaruh kemampuan dan motivasi terhadap kinerja pegawai pada Sekolah Tinggi Seni Indonesia (STSI) Bandung. Jurnal Penelitian Pendidikan, Vol 12 No. 2, Oktober 2011

Abdulrachman \& Sustin, Y. (2014). Pengaruh Motivasi dan Kemampuan Kerja Terhadap Kinerja Pegawai di Badan Kepegawaian Daerah dan Diklat Kabupaten Ciamis. Ekonologi: Jurnal Ilmu Manajemen, Vol 1, No 1, 2014

Dhermawan, A.G.N.B, Sudibya, I.G.A, Utama, I.W.M (2012). Pengaruh Motivasi, Lingkungan Kerja, Kompetensi, Dan Kompensasi Terhadap Kepuasan Kerja Dan Kinerja Pegawai Di Lingkungan Kantor Dinas Pekerjaan Umum Provinsi Bali. Jurnal Manajemen, Strategi Bisnis, dan Kewirausahaan, Vol. 6, No. 2, Agustus 2012.

Dewi, K \& Hardi. (2015). Pengaruh etos kerja, insentif dan pengembangan karir terhadap kinerja karyawan departemen cutting PT Morichindo Fashion ungaran, Among Makarti, Vol 8, No.16, Desember 2015. 
Kartika, L.N \& Sugiarto, A. (2014). Pengaruh Tingkat Kompetensi Terhadap Kinerja Pegawai Administrasi Perkantoran. Jurnal Ekonomi dan Bisnis, Volume 17, No. 1, April 2014

Hasibuan, Malayu S.P. (2014). Manajemen Sumberdaya Manusia. Jakarta: PT Bumi Aksara.

Mangkunegara, Anwar Prabu. (2013). Manajemen Sumberdaya Manusia Perusahaan. Bandung: PT Remaja Rosdakaya.

Mangkunegara, Anwar Prabu. (2017). Evaluasi Kinerja SDM. Bandung: PT Refika Aditama.

Meidianwar, P, A. Margono \& Djumadi. (2014). Pengaruh Kemampuan Kerja dan Motivasi Kerja Terhadap Kinerja Pegawai pada Lembaga Penyiaran Publik Televisi Republik. Jurnal Administrative Reform, Vol.2 No.4,Desember 2014

Sulistiani, S.Y. (2016). Pengaruh Kemampuan Kerja Dan Keterampilan Kerja Terhadap Kinerja Pegawai Perusahaan Leasing, Ekonologi: Jurnal Ilmu Manajemen, Vol 3, No 2, 2016

Syaifuddin. (2016). Pengaruh Kompetensi dan Motivasi Terhadap Kinerja Karyawan Pada PT. Putra Fajar Jaya, Medan. Agrica: Jurnal Agribisnis Sumatera Utara, Vol 9, No 2.

Yuningsih, E \& Ardianti. (2019). Pengaruh Kompetensi dan Motivasi terhadap Kinerja Pegawai pada PT XXX. Jurnal Visionida, Volume 5, Nomor 1 Juni 2019 